\section{The varieties of visual persistence: Comments on Yeomans and Irwin}

\author{
GERALD M. LONG \\ Villanova University, Villanova, Pennsylvania
}

In a recent article, Yeomans and Irwin (1985) entered the current controversy about the nature and function of visual persistence, or iconic memory. Specifically, they reported no effect of varying target duration on a standard Sperling (1960) partial-report task, from which they concluded that such a task involves an energyindependent, nonvisible, informational persistence. Moreover, they proposed a two-stage model of visual persistence in order to incorporate these findings with those of other researchers who have reported significant energy effects on some visual persistence tasks. The first stage in their model is that of a brief (less than $300 \mathrm{msec}$ ) visible persistence that is inversely related to target energy (luminance or duration); the second stage is that of an informational persistence that can persist from 300 to $600 \mathrm{msec}$, independent of target intensity, and that may well be nonvisible in character. As Yeomans and Irwin noted, this model shares some characteristics with the alternate models of iconic memory suggested by Coltheart (1980) and DiLollo (1978, 1980).

The purpose of the present note is to comment on both the logic of the Yeomans and Irwin procedure and the comprehensiveness of the model they propose with regard to the body of current empirical results. To anticipate the line of argument to follow, it will be contended that (1) a null effect is a logically weak position on which to base a model-especially given a notoriously complex and "noisy" experimental task-and (2) there are numerous published results that are inconsistent with the two-stage model favored by Yeomans and Irwin.

\section{The Problem with the Null Effect}

First, let me address the issue of the null effect of the duration manipulation obtained by Yeomans and Irwin (1985). The famous Sperling partial-report task is not an easy task for naive subjects; more accurately, although it is rather easily understood, it is not easily performed. Many investigators over the years have reported this fact. In Sperling's seminal work (1960), in which this procedure was first introduced, even nonmonotonic decay functions with increasing cue delay were occasionally reported; and Sakitt $(1975,1976)$ obtained the same pattern of results for one subject in her oft-cited research

The author would like to thank Charles W. Eriksen for his comments on an earlier draft of this paper. Requests for reprints should be sent to Gerald M. Long, Department of Psychology, Villanova University, Villanova, PA 19085. with the partial-report task. Both Sperling and Sakitt interpreted such unlikely patterns in terms of unusual response strategies by some subjects. In a more recent study by Appelman (1980), only one of eight subjects exhibited the "classic" monotonic decay function on a partial-report task, but the more typically reported group data portray just such a smooth fall-off in performance over increasing cue delay. The point to be made here is not an indictment of the popular partial-report task but a realization that it is not a "pure" persistence measure. This is by no means a novel claim. In the early 1970 s, there was extensive debate over the clarity of results obtained with the partial-report task (cf. Coltheart, Lea, \& Thompson, 1974; Holding, 1970, 1971, 1973). As a result, it is generally agreed that the partial-report task, in addition to any persistence effects it may reveal, also involves a number of other processes, including output interference, cue interpretation time, cue anticipation (guessing) effects, processing strategies (e.g., left-to-right, top-to-bottom preferences), masking effects, and more (see, for example, Holding, 1975; Long, 1980; Mewhort, Campbell, Marchetti, \& Campbell, 1981). Given the variety of processes involved, it is not surprising that subjects exhibit wide individual differences under identical stimulus conditions.

In a recently published study, a colleague and I (Long \& Beaton, 1982) employed a modified version of the partial-report task (see Keele \& Chase, 1967) in which a circular array of eight letters was followed after a variable interval by a probe marker indicating the single letter from the array to be reported. (This version of the partial-report task avoids the problem of output interference because of the single-item response, and it maintains item clarity for all letters because of the constant retinal eccentricity of all array items.) We found extensive individual differences and extremely noisy data when using unpracticed observers in pilot work. Therefore, in the actual experiment, each subject was given a 60 -min practice session before being run for four 60 - to 90 -min experimental sessions. Directly contrary to Yeomans and Irwin's predictions, clear effects of target and background luminance on performance were obtained from this procedure. Relevant to the present argument, I strongly doubt that such findings would have been obtained without the long practice session or with only two 60-min experimental sessions. Yet, the latter procedure was employed by Yeomans and Irwin (1985). Moreover, the use of wellpracticed subjects in partial-report research is quite typical of previous studies because of wide subject variability (e.g., Coltheart, Lea, \& Thompson, 1974; Doost \& Turvey, 1971; Eriksen \& Collins, 1969; Eriksen \& Rohrbaugh, 1970; Marzi, DiStefano, Tassinari, \& Crea, 1979; Merluzzi \& Johnson, 1974; Sakitt \& Appelman, 1978; Turvey, 1967; von Wright, 1972). Consequently, it is difficult to know what to make of the null effect reported 
by Yeomans and Irwin. Would they have obtained the same result if they had used an experimental design with more power? To borrow a quote from a very different context, "absence of evidence is not evidence of absence" (Sagan, 1977, p. 7).

Finally, there is a particular problem with the partialreport task, a problem elegantly described by Coltheart (1980). It concerns the issue of the "initial registration" of the brief target array (Coltheart, 1980, p. 208). Suppose that, with greater practice and more experimental trials, the subjects in the Yeomans and Irwin study began to exhibit higher performance levels with the longer target durations (which I would predict). How much of such an improvement could be interpreted in terms of increased persistence with longer durations, as opposed to improved target clarity? A 50-msec target is dimmer and less distinct than a 200 -msec target. Hence, the resulting decay functions obtained for these two durations are confounded by the degraded nature of the $50-\mathrm{msec}$ array compared to the 200 -msec array. This point makes the unambiguous interpretation of positive energy effects on the partialreport task very difficult.

\section{Yeomans and Irwin's Two-Stage Model: The Overlooked Persistence}

As noted above, Yeomans and Irwin (1985) proposed a two-stage model of persistence in order to incorporate their energy-independent informational persistence with the inverse-energy visible persistence reported by several other investigators (e.g., Bowen, Pola, \& Matin, 1974; Bowling \& Lovegrove, 1980; DiLollo, 1977; Efron, 1970 ). Besides the issue raised in the previous section concerning the difficulty of interpreting a null effect as strong evidence for an informational persistence, there is an equally serious problem, posed by several empirical studies, that cannot be accommodated by this two-part classification scheme. Specifically, several studies over the past two decades have provided clear evidence for a positive-energy persistence that outlasts target offset by several hundred milliseconds (Eriksen \& Collins, 1968; Eriksen \& Rohrbaugh, 1970; Long, 1984, 1985; Long \& Beaton, 1982; Long \& McCarthy, 1982a, 1982b; Long \& Sakitt, 1980, 1981; Sakitt, 1975, 1976; Sakitt \& Long, 1978, 1979a, 1979b). Yeomans and Irwin (1985) have overlooked these studies, which would appear to require that their model be broadened to encompass all the experimental data. In the terminology originally suggested by Hawkins and Shulman (1979), Yeomans and Irwin's model omits the Type II persistence phenomenon found in various persistence tasks (see also Long, 1979, 1982).

Other current theorists have also tended to downplay the possible role of a robust, positive-energy persistence (e.g., Coltheart, 1980; DiLollo, 1980, 1984). There are at least two likely reasons for this. First, much of the early work with this type of persistence employed somewhat atypical viewing conditions, using, for example, darkadapted observers and relatively high target energy levels (e.g., Keele \& Chase, 1967; Sakitt \& Long, 1978, 1979a). As I have noted elsewhere (Long, 1982a), in many cases these atypical conditions were used intentionally, in order to optimize the viewing environment for assessing the potential role of retinal processes in the persistence being assessed. Nevertheless, several investigators have criticized the apparent atypicality of these conditions and have suggested that different visual processes may be accessed under such conditions (Adelson, 1978; Banks \& Barber, 1977; Coltheart, 1980; DiLollo, 1984). However, other research has extended the findings of strong positive luminance, duration, size, and wavelength effects on visual persistence to more typical viewing conditions as well (e.g., Eriksen \& Rohrbaugh, 1970; Long \& Beaton, 1982; Long \& McCarthy, 1982b; Long \& Sakitt, 1981; Sakitt \& Long, 1979b). The findings of these studies cannot be accommodated by the two-stage Yeomans and Irwin model.

The second likely reason for the frequent exclusion of Type II persistence from current considerations of visual persistence/iconic memory is its dependence on the type of persistence task used. There is increasing evidence that different persistence tasks may be accessing different persistence processes (e.g., Breitmeyer, 1984; Sakitt \& Long, 1979a; Wilson, 1983). If these different processes exhibit different functional relationships with stimulus variables, it is not surprising that individual studies may report relationship A or relationship B, depending upon the particular experimental task employed. To make this final point a bit more strongly, Table 1 presents a representative sample of persistence studies, but each study is classified in terms of the kind of visual persistence revealed by its relationship with stimulus parameters. The studies are also grouped according to the particular persistence task used. The asynchrony-judgment task is a very simple procedure in which the observer adjusts a brief probe (e.g., a 20msec tone) to coincide with the offset of a target. Some persistence studies have used moving stimuli that leave phenomenal streaks or multiple impressions from the persisting target at its various positions. Other studies have employed flickering stimuli or multielement presentations that involve perceived simultaneity or continuity of the sensory impressions from the physically discontinuous target stimuli. The probe-matching task is very similar to the asynchrony-judgment task above, but the observer adjusts the probe to coincide with the disappearance of any trace of the fading target (rather than target offset). It has been demonstrated that very different patterns of results are obtained with the two probe procedures (e.g., Sakitt \& Long, 1979a). The successive-field task, originally introduced by Eriksen and Collins $(1967,1968)$, requires the observer to integrate two successively presented halfstimuli in order to identify correctly the composite form. Finally, the ingenious partial-report task devised by Sperling (1960) is the procedure employed by Yeomans and Irwin (1985): The subject reports that item in a multi-item array that is indicated by a brief probe marker presented at some point after array offset.

The major point to be drawn from Table 1 concerns the apparent segregation of results by the type of persistence task used. Consider first the left and center columns. 
Table 1

Representative Sample of Visual Persistence/Iconic Memory Studies Categorized by Nature of Persistence Assessed and Type of Persistence Task Used

\begin{tabular}{|c|c|c|}
\hline Type I Persistence* & Type II Persistence $\dagger$ & Informational Persistence $\ddagger$ \\
\hline $\begin{array}{l}\text { Asynchrony-Judgment Task } \\
\text { Efron (1970) } \\
\text { Bowen, Pola, \& Matin (1974) } \\
\text { Long \& Gildea (1981) } \\
\text { Long \& McCarthy (1982b) } \\
\text { Wilson (1983) } \\
\text { Moving Target Task } \\
\text { Allport (1968) } \\
\text { Smith (1969) } \\
\text { Dixon \& Hammond (1972) } \\
\text { Farrell (1984) } \\
\text { Flicker/Multiflash Task } \\
\text { Haber \& Standing (1969) } \\
\text { Hogben \& DiLollo (1974) } \\
\text { DiLollo (1977, 1980) } \\
\text { DiLollo \& Wilson (1978) } \\
\text { Meyer \& Maguire (1977, 1981) } \\
\text { Bowling, Lovegrove, \& Mapperson (1979) } \\
\text { Bowling \& Lovegrove (1980, 1981) } \\
\text { Marx \& May (1983) } \\
\text { Long \& Sakitt (1981, 1984) } \\
\text { Lovegrove \& Meyer (1984) }\end{array}$ & $\begin{array}{l}\text { Probe-Matching Task } \\
\text { Sakitt (1976) } \\
\text { Sakitt \& Long (1979a) } \\
\text { Long \& Beaton (1980, 1981) } \\
\text { Long \& McCarthy (1982b) } \\
\text { Long (1984) } \\
\text { Long \& Sakitt (1984) } \\
\text { Long \& Wurst (1984) } \\
\text { Long (1985) } \\
\text { Successive-Field Task } \\
\text { Eriksen \& Collins (1968) } \\
\text { Sakitt \& Long (1978, 1979b) } \\
\text { Long \& Sakitt (1980) } \\
\text { Kinnucan \& Friden (1981) } \\
\text { Long (1982) } \\
\text { Partial-Report Task } \\
\text { Keele \& Chase (1967) } \\
\text { Eriksen \& Rohrbaugh (1970) } \\
\text { Sakitt (1976) } \\
\text { Long \& Beaton (1982) } \\
\text { Long \& McCarthy (1982a) } \\
\text { Kling \& Long (1983) }\end{array}$ & $\begin{array}{l}\text { Letter-Comparison Task } \\
\text { Posner \& Keele (1967) } \\
\text { Dot-Matrix Discrimination Task } \\
\text { Phillips (1974) } \\
\text { Repetition-Detection Task } \\
\text { Sperling \& Kaufman (1978) } \\
\text { Picture-Masking Task } \\
\text { Loftus, Johnson, \& Shimamura } \\
\quad \text { (1985) }\end{array}$ \\
\hline
\end{tabular}

Three popular persistence tasks have been employed in studies that have produced inverse luminance, duration, and size effects on persistence (left column); three other tasks have been used in studies that have produced positive luminance, duration, and size effects on persistence (center column). This suggests at least two classes of persistence phenomena. Moreover, perhaps the particular conditions of some of the tasks "eliminate" one of the two types of persistence. As Breitmeyer $(1980,1984)$ has cogently argued, it would behoove the visual system for the sake of efficiency in many situations to eliminate persistence effects from early levels in the system (see also Haber, 1983, 1985, and Schurman, Eriksen, \& Rohrbaugh, 1968). The inhibitory mechanisms Breitmeyer suggested to serve this function are dependent upon signals in the transient channels. These transient signals, in turn, would be most pronounced in situations with abrupt onsets and offsets, flicker, and movement, that is, in the very tasks represented in the left column of Table 1. This may be one reason for the lack of comparability across persistence procedures. This proposal, which has the clear advantage of freeing the field from attempting to integrate the wide variety of discrepant but replicable findings into a single-process model, needs now to be put to a direct empirical test.

Finally, consider the right column of Table 1 . Several studies cannot be readily accommodated by either the inverse-energy persistence or the positive-energy persistence category. These include the Posner and Keele (1967) letter-comparison task, the Loftus, Johnson, \&
Shimamura (1985) picture-masking task, the Phillips (1974; Phillips \& Singer, 1974) dot-matrix discrimination task, the Sperling and Kauman (1978; Sperling, 1983) repetition-detection task, and possibly others. These studies seem to indicate a robust persistence, often far greater than that obtained by the previously mentioned tasks, that may be both independent of target energy and not tied to retinal location (i.e., spatiotopic rather than retinotopic). Occasionally this persistence has been explicitly distinguished from visual persistence, or sensory store, and has been described as "short-term visual memory" (e.g., by Phillips, 1974) or "informational" persistence (Loftus, Johnson, \& Shimamura, 1985). Moreover, this third type of persistence may well play a role in the other persistence tasks as well-perhaps even in the partial-report task, as Coltheart (1980) and Yeomans and Irwin (1985) suggest. This is an interesting question for future research.

In anticipation of possible objections to my choice of categorization in Table 1, there are two points on which I should elaborate. First, I have distinguished between the successive-field task of Eriksen and Collins (1968; center column) and the multiple-flash task of DiLollo (1977, 1980; DiLollo \& Wilson, 1978; left column), even though DiLollo (1980, 1984) and others (e.g., Breitmeyer, 1984) consider the two tasks to be equivalent. I base the distinction on the fact that DiLollo's task requires the perceived simultaneity of the 24 successive dots contained in the brief "plotting interval." When perceived simultaneity of the physically successive dots is exceeded (even 
by $10 \mathrm{msec}$ ), performance suffers markedly. On the other hand, observers in the original Eriksen and Collins (1967, 1968) research and in later replications (Long \& Sakitt, 1980; Sakitt \& Long, 1979b), all of which require the simple integration of two successive half-stimuli, have described a gradually fading trace of a stimulus that can last for hundreds of milliseconds, long after the perceived simultaneity of the two components has broken down. Several years ago, Eriksen and his colleagues (Eriksen \& Collins, 1968, 1969; Schurman, Eriksen, \& Rohrbaugh, 1968) argued on both logical and empirical grounds that "discontinuity detectors" within the visual system served to disrupt temporal integration. Such detectors would be extensively engaged by the discontinuous presentation of the 24 sequential dots in the DiLollo task. According to this view, it is not surprising that the Eriksen and Collins task, in which integration is critical, and the DiLollo task, in which integration is minimized, are very different phenomenally. In addition, the DiLollo task and the Eriksen and Collins task also appear to exhibit very different relationships with stimulus variables (see Table 1), which strongly suggests the involvement of different processes across the tasks.

The second potential criticism of the trichotomy proposed in the table is that each of the various persistence tasks is located in only a single column. As suggested above, the conditions of some persistence tasks may actually eliminate certain types of persistence phenomena. However, it appears quite plausible that a particular persistence task might involve more than a single type of persistence. This would seem to be especially true for the nonvisible persistence tasks depicted on the right in Table 1: either of the two types of visible persistence might contribute to performance on these tasks. In fact, Loftus et al. (1985; Loftus, 1985) recently suggested this possibility in relation to the persistence from brief pictures (see also Phillips, 1974). Hence, the location of a particular task in the columns of Table 1 is not meant to be completely exclusionary. How and under what conditions the various types of persistence may work together is an interesting area for future research.

I believe that the three-part classification of persistence types described in Table 1 fits the current empirical literature much more completely than the two-part model of Yeomans and Irwin (1985) or the related models proposed by others. Moreover, it does not deny the classifications proposed by them; it simply provides an additional category in order to accommodate more of the extensive persistence literature.

\section{REFERENCES}

AdELSON, E. H. (1978). Iconic storage: The role of rods. Science, 201,544-546.

AlLPORT, D. A. (1968). Phenomenal simultaneity and the perceptual moment hypothesis. British Journal of Psychology, 59, 395-406.

APPELMAN, I. B. (1980). Partial report and other sampling procedures overestimate the duration of iconic memory. American Journal of Psychology, 93, 79-97.

Banks, W. P., \& Barber, G. (1977). Color information in iconic memory. Psychological Review, 84, 536-546.
Bowen, R. W., Pola, J., \& Matin, L. (1974). Visual persistence: Effects of flash luminance, duration and energy. Vision Research, 14, 295-303.

Bowling, A., Lovegrove, W., \& Mapperson, B. (1979). The effect of spatial frequency and contrast on visual persistence. Perception, $8,529-539$.

Bowling, A., \& Lovegrove, W. (1980). The effect of stimulus duration on the persistence of gratings. Perception \& Psychophysics, 27, 574-578.

Bowling, A., \& Lovegrove, W. (1981). Two components to visible persistence: Effects of orientation and contrast. Vision Research, 21, 1241-1251.

BREITMEYer, B. G. (1980). Unmasking visual masking: A look at the "why" behind the veil of the "how." Psychological Review, 87, 52-69.

BREITMEYER, B. (1984). Visual masking: An integrative approach. New York: Oxford University Press.

Coltheart, M. (1980). Iconic memory and visible persistence. Perception \& Psychophysics, 27, 183-228.

ColthearT, M., LEA, C. D., \& Thompson, K. (1974). In defense of iconic memory. Quarterly Journal of Experimental Psychology, 26, 633-641.

DiLollo, V. (1977). Temporal characteristics of iconic memory. Nature, 267, 241-243.

DiLoLlo, V. (1978). On the spatio-temporal interactions of brief visual displays. In R. H. Day \& G. V. Stanley (Eds.), Studies in perception (pp. 39-55). Perth: University of Western Australia Press.

DiLollo, V. (1980). Temporal integration in visual memory. Journal of Experimental Psychology: General, 109, 75-97.

DiLoLlo, V. (1984). On the relationship between stimulus intensity and duration of visible persistence. Journal of Experimental Psychology: Human Perception \& Performance, 10, 144-151.

DiLollo, V., \& Wilson, A. E. (1978). Iconic persistence and perceptual moment as determinants of temporal integration in vision. $\mathrm{Vi}$ sion Research, 18, 1607-1610.

Dixon, N. F., \& Hammond, J. (1972). The attenuation of visual persistence. British Journal of Psychology, 63, 243-254.

Doost, R., \& TuRvey, M. T. (1971). Iconic memory and central processing capacity. Perception \& Psychophysics, 9, 269-274.

EFRON, R. (1970). The relationship between the duration of a stimulus and the duration of a perception. Neuropsychologia, 8, 37-55.

Eriksen, C. W., \& Collins, J. F. (1967). Some temporal characteristics of visual pattern perception. Journal of Experimental Psychology, 74, 476-484.

Eriksen, C. W., \& Collins, J. F. (1968). Sensory traces versus the psychological moment in the temporal organization of form. Journal of Experimental Psychology, 77, 376-382.

Eriksen, C. W., \& Collins, J. F. (1969). Temporal course of selective attention. Journal of Experimental Psychology, 80, 254-261.

Eriksen, C. W., Rohrbaugh, J. (1970). Visual masking in multielement displays. Journal of Experimental Psychology, 83, 147-154.

FARRELL, J. E. (1984). Visible persistence of moving objects. Journal of Experimental Psychology: Human Perception \& Performance, 10, 502-511.

HABER, R. N. (1983). The impending demise of the icon: A critique of the concept of iconic storage in visual information processing. The Behavior \& Brain Sciences, 6, 1-54.

HaBER, R. N. (1985). An icon can have no worth in the real world: Comments on Loftus, Johnson and Shimamura's "How much is an icon worth?" Journal of Experimental Psychology: Human Perception \& Performance, 11, 374-378.

Haber, R. N., \& Standing, L. (1969). Direct measures of short-term visual storage. Quarterly Journal of Experimental Psychology, 21, 43-54.

Hawkins, H. L., Shulman, G. L. (1979). Two definitions of persistence in visual perception. Perception \& Psychophysics, 25, 348-350.

Hogben, J. H., \& Dilollo, V. (1974). Perceptual integration and perceptual segregation of brief visual stimuli. Vision Research, 14, 1059-1069.

Holding, D. H. (1970). Guessing behavior and the Sperling store. Quarterly Journal of Experimental Psychology, 22, 248-256. 
Holding, D. H. (1971). The amount seen in brief exposures. Quarterly Journal of Experimental Psychology, 23, 72-81.

HoldiNG, D. H. (1973). Recognition tests of visual information storage. British Journal of Psychology, 64, 9-16.

HoldiNG, D. H. (1975). Sensory storage reconsidered. Memory \& Cognition, 3, 31-41.

Keele, S. W., \& Chase, W. G. (1967). Short-term visual storage. Perception \& Psychophysics, 2, 383-386.

KinNUCAN, M. T., \& Friden, T. P., (1981). Visual form integration and discontinuity detection. Journal of Experimental Psychology: Human Perception \& Performance, 7, 948-953.

KLING, S. C., \& Long, G. M. (1983). The effects of target size and retinal location on a partial report task of iconic memory. Bulletin of the Psychonomic Society, 21, 435-438.

LofTus, G. R. (1985). On worthwhile icons: A reply to DiLollo and Haber. Journal of Experimental Psychology: Human Perception \& Performance, 11, 384-388.

Lofius, G. R., Johnson, C. A., \& Shimamura, A. P. (1985). How much is an icon worth? Journal of Experimental Psychology; Human Perception \& Performance, 11, 1-13.

LoNG, G. M. (1979). Comment on Hawkins and Shulman's Type I and Type II visual persistence. Perception \& Psychophysics, 26, 412-414.

LoNG, G. M. (1980). Iconic memory: A review and critique of the study of short-term visual storage. Psychological Bulletin, 88, 785-820.

LoNG, G. M. (1982a). Persisting problems in persistence: A reply to Bowling and Lovegrove. Perception \& Psychophysics, 32, 192-194.

LoNG, G. M. (1982b). Receptor interactions and visual peresistence. Vision Research, 22, 1285-1292.

LoNG, G. M. (1984). The pretreatment weighting technique. Journal of Experimental Psychology: Human Perception \& Performance, 10, 40-43.

LoNG, G. M. (1985). Visual persistence from brief letters and pictures. Vision Research, 25, 887-892.

LoNG, G. M. , \& BEATON, R. J. (1980). The contribution of visual persistence to the perceived duration of brief targets. Perception \& Psychophysics, 28, 422-430.

LONG, G. M., \& BeATON, R. J. (1981). The effects of stimulus numerosity, retinal location, and rod contrast on perceived duration of brief visual stimuli. Perception \& Psychophysics, 29, 389-394.

LONG, G. M., \& BEATON, R. J. (1982). The case for peripheral persistence: Effects of target and background luminance on a partial-report task. Joumal of Experimental Psychology: Human Perception \& Performance, 8, 383-391.

LoNG, G. M., \& GiLDEA, T. J. (1981). Latency for the perceived offset of brief target gratings. Vision Research, 21, 1395-1399.

LONG, G. M., \& MCCARTHY, P. R. (1982a). Rod persistence on a partialreport task with scotopic and photopic backgrounds. American Journal of Psychology, 95, 302-322.

LoNG, G. M., \& McCARTHY, P. R. (1982b). Target energy effects on Type 1 and Type 2 visual persistence. Bulletin of the Psychonomic Society, 19, 219-221.

LoNG, G. M., \& SAKITT, B. (1980). The retinal basis of iconic memory: Erikson and Collins revisited. American Journal of Psychology, 93, 195-207.

Long, G. M., \& SAKITT, B. (1981). Differences between flicker and nonflicker persistence tasks: The effects of luminance and the number of cycles in a grating target. Vision Research, 21, 1387-1393.

LoNG, G. M., SAKITT, B. (1984). Visual persistence from flickered and flashed gratings: Methodological considerations. Bulletin of the Psychonomic Society, 22, 1-4

LoNG, G. M., \& WURST, S. A. (1984). Complexity effects on reactiontime measures of visual persistence: Evidence for peripheral and central contributions. American Journal of Psychology, 97, 537-561.
Lovegrove, W. J., \& MeYer, G. E. (1984). Visible persistence as a function of spatial frequency, number of cycles and retinal area. Vision Research, 24, 255-260.

MarX, M. S., \& MAY, J. G. (1983). The relationship, between temporal integration and persistence. Vision Research, 23, 1101-1106.

Marzi, C. A., DiStefano, M., Tassinari, G., \& Crea, F. (1979). Iconic storage in the two hemispheres. Journal of Experimental Psychology: Human Perception \& Performance, 5, 31-41.

MerluZZi, T. V., \& Johnson, N. F. (1974). The effect of repetition on iconic memory. Quarterly Journal of Experimental Psychology, 26, 266-273.

Mewhort, D. J. K., Campbell, A. J., Marchetti, F. M., \& CampBELL, J. I. D. (1981). Identification, location, and "iconic memory": An evaluation of the bar-probe task. Memory \& Cognition, 9, 50-67.

MeYer, G. E., \& MAGUire, W. M. (1977). Spatial frequency and the mediation of short-term visual storage. Science, 198, 524-525.

MEYER, G. E., \& MAGUIRE, W. M. (1981). Effects of spatial-frequency specific adaptation and target duration on visual persistence. Journal of Experimental Psychology: Human Perception and Performance, 7, 151-156.

PhILliPS, W. A. (1974). On the distinction between sensory storage and short-term visual memory. Perception \& Psychophysics, 16, 283-290.

PhilliPs, W. A., \& Singer, W. (1974). The function and interaction of "on" and "off" transients in vision. I. Psychophysics. Experimental Brain Research, 19, 493-506.

POSNER, M. I., \& KEELE, S. W. (1967). Decay of visual information from a single letter. Science, 158, 137-139.

SAGAN, C. (1977). The dragons of Eden. New York: Ballantine Books.

SAKITT, B. (1975). Locus of short-term visual storage. Science, 190, 1318-1319.

SAKITT, B. (1976). Iconic memory. Psychological Review, 83, 257-276.

SAKITT, B., \& APPELMAN, J. B. (1978). The effects of memory load and the contrast of the rod signal on partial report superiority in a Sperling task. Memory \& Cognition, 6, 562-567.

SAKITT, B., LoNG, G. M. (1978). Relative rod and cone contributions in iconic storage. Perception \& Psychophysics, 23, 527-536.

SAKITT, B., \& LoNG, G. M. (1979a). Cones determine subjective offset of a stimulus but rods determine total persistence. Vision Research, 19, 1439-1441.

SAKITt, B., \& Long, G. M. (1979b). Spare the rod and spoil the icon. Journal of Experimental Psychology: Human Perception \& Performance, 5, 19-30.

Schurman, D. L., Eriksen, C. W., \& Rohrbaugh, J. (1968). Masking phenomena and time intensity reciprocity for form. Journal of Experimental Psychology, 78, 310-317.

SMITH, V. C. (1969). Scotopic and photopic functions for visual band movement. Vision Research, 9, 293-304.

SPERLING, G. (1960). The information available in brief visual presentations. Psychological Monographs, 74(11, Whole No. 498).

SPERLING, G. (1983). Why we need iconic memory. The Behavioral and Brain Sciences, 6, 37-39.

Sperling, G., \& Kaufman, J. (1978, August). Three kinds of visual short-term memory. Paper presented at the Eighth International Symposium on Attention and Performance, Princeton, NJ.

TURVEY, M. T. (1967). Repetition and the preperceptual information store. Joumal of Experimental Psycholgoy, 74, 289-293.

voN WRIGHT, J. M. (1972). On the problem of selection in iconic memory. Scandinavian Journal of Psychology, 13, 159-171.

WILSON, J. T. L. (1983). Effects of stimulus luminance and duration on responses to onset and offset. Vision Research, 23, 1699-1709.

YEOMANS, J. M., \& IRWIN, D. E. (1985). Stimulus duration and partial report performances. Perception \& Psychophysics, 37, 163-169.

(Manuscript received June 10, 1985; revision accepted for publication September 18, 1985.) 